\title{
The Implementation of Andragogy to Pedagogy Approach in Learning Process at Lentera Bangsa Community Homeschool as an Optimization of Students' Potencies
}

\author{
Tiffany Estherlita \\ Non-Formal Education Departemen \\ STKIP Siliwangi Bandung \\ Bandung, Indonesia \\ tiffanyestherlita@gmail.com
}

\begin{abstract}
Each learner both children and adult is a complete human being who has a different self-concept and learning motivation, experience, readiness to learn and learning orientation. The aim of this research is to optimizing the student potency by providing solutions to the academic learning program with a difference in the speed of learning (capture, understand and work) and motivation of each student in Lentera Bangsa Community Homeschool. The concept of this study is adopting the andragogy to pedagogy approach. The methods used in this research are brainstorming, observation and experimental design method. Data are collected by using observation and interview. This research resulted a concept of andragogic to pedagogical approach which is able to optimize the students' potency; and received a positive response from teachers, students and parents; so it will give a positive impact on the learning process and the increase of student's motivation.
\end{abstract}

Keywords-andragogical to pedagogical, learning speed, student's motivation, self-targeting.

\section{INTRODUCTION}

Education has a very important role in terms of optimizing the potency of learners. However, until now the educational process designed is still cannot "create" a student as a valuable person. There are a lot of students who lost their way when they complete their education. Based on experience and observations in the learning process at Lentera Bangsa Community Homeschool, researcher found a problem in the differences at the speed of learning (capture, understand and work) from each student and the learning motivation of students which makes the learning process with pedagogical approach becomes less optimal. This clearly indicates a serious problem in learning activities at Lentera Bangsa community home school and should be solve immediately. As an effort to solve the problems, the researcher conducted an andragogical to pedagogical approach. As we know, the appropriate use of learning process can help students in optimizing their potencies.
Pedagogy is the art and science of educating children. In the concept of this approach, educators are dominant to become the learning center. All learning activities such as planning, implementation and evaluation of the learning process which are carried out by educators often make the students become less participating in the learning process. On some classical based learning method, students are required to have the same learning speed and it is measured based on a standard Rancangan Program Pembelajaran (RPP). This RPP is refer to a curriculum. In Lentera Bangsa Community Homeschool, researcher found that the pedagogical approach is not fully applicable in the learning process, because each child or individual has a different speed of learning (catch and working) and cannot be measured in the same standard.

Basically, andragogy is the art and science which is are used to help adults in learning. Knowles in Jarvis (2004) has the following assumptions: (1) The concept of self and motivation to learn: adults need to be involved in the planning and evaluation of learning that they follow. (2) The concept of experience: experience (including error) is the basis for the activity. (3) Readiness to learn: adults are most interested in learning subjects that have immediate relevance to their work or personal life. (4) Learning orientation: learning for adults is more focused on issues rather than on its contents. Researcher feels that andragogical approach can be applied in Lentera Bangsa Community Homeschool's learning process. Because every child is an individual which has a self-concept and learning motivation, has experience in their daily activities, will have a greater interest in the subjects that has direct relevance to their personal life, and being able to learn with the problem resolution orientation.

The application of the learning concept that combines two models of approaches, namely andragogical and pedagogical approach, can be a good formula in the learning process and will give a positive impact if each approach is combined with the right composition. Educators and students are able to complete each other and play an active role in the learning process, thereby reducing the negative impact of the error from 
the learning programs that could potentially make one party feels pressured for not achieving the learning program's objectives.

Andragogical to pedagogical approach, which is applied at Lentera Bangsa Community Homeschool, emphasize that every individual, both educators and students are entitled to enjoy and feel comfortable with the learning process implemented in this place. Educators who understand the needs of students, that every child has a different learning speed (capture, understand and work) and have different interest depending on each subject, cannot generalize every child to the same standard or size. Thus, students can learn in a way that they like and educators should not force their students to be at the same level in the same subject with other students. So that every educator and students are able to measure the ability or capacity of such students.

\section{METHODS}

The methods used in this research are brainstorming, observation and experimental design method. The population in this research is the level 3 students, period of 2015-2016 at Lentera Bangsa Community Homeschool. The sampling technique in this research is using purposive sampling technique. This technique is suitable to use in this study because the number of samples taken is only at the level 3 students, period of 2015-2016 at Lentera Bangsa Community Homeschool. The total of sample is 8 people.

\section{A. Identification of Need Program}

This andragogical to pedagogical approach based learning program is designed so that the learning process at Lentera Bangsa Community Homeschool can run optimal in accordance with the conditions and the needs of the learning process in order to support the optimization of students' potency.

\section{B. Preparing a Program Plan}

In detailed, the planning phases in this study are:

1. Identifying the problem and establishing the alternative solutions.

2. Planning a learning plan that will be applied in the learning process.

3. Choosing the appropriate lesson material.

4. Determining learning scenarios with an andagrogical to pedagogical approach models.

5. Preparing resources, materials, and tools which are needed.

6. Developing a worksheet.

7. Developing an evaluation format.

8. Developing a learning observation format.

\section{Program Socialization}

Andragogical to pedagogical approach program socialization stages in the learning process at Lentera Bangsa Community Homeschool are:
1. To suggest a problem founded by researcher to the management team and the teachers.

2. To suggest alternative solutions to the management team and the teachers.

3. To discuss learning program based on andragogical to pedagogical approach to the management team and the teachers.

4. To provide informations about the determination of the learning program to the students' parents.

\section{Implementation and Evaluation}

In the implementation phase, the researcher gives indicators of this study with increased learning outcome and increased learning motivation of students. Action taken, which is refer to the learning scenarios (lesson plans), is learning used andragogical to pedagogical approach. Stages of action implementation are as follows: giving freedom to the students to determine their learning targets, monitoring all kinds of condition and potency while the learning process take place, evaluating the learning process.

The evaluation process of the program conducted by researcher is using interviews and discussions with teachers and parents of students, as well as the collection of observation data.

\section{RESULTS AND DISCUSSIONS}

\section{A. The concept of Andragogy to Pedagogy in the Learning} Process as Optimization of Students' Potencies

The concept of andragogy to pedagogy, which is applied in the learning process at Lentera Bangsa Community Homeschool, is still refer to the 2006 Education Unit Level Curriculum and the 2013 National Curriculum, where each classroom teachers and subject teachers is released to design or develop Core Competencies, Basic Competencies, Competence Achievement Indicators, Learning Materials, Time Allocation, Learning Method, Learning Media and Learning Resources based on Subject Matter and Learning Objectives in accordance with the needs of the classroom and the needs of each children. Below is the level 3 Lentera Bangsa Community Home School's learning schedule in one month:

TABLE I. LEVEL 3 LEARNING SCHEDULE

\begin{tabular}{llllll}
\hline $\begin{array}{l}\text { Day } \\
\text { Week }\end{array}$ & Monday & Tuesday & $\begin{array}{l}\text { Wedne } \\
\text { sday }\end{array}$ & $\begin{array}{l}\text { Thurs } \\
\text { day }\end{array}$ & Friday \\
\hline 1 & Morning & English & Mornin & Mornin & Morning \\
& Dew & Fruit & g Dew & g Dew & Dew \\
& Civic & Time & Indones & Math & Motivati \\
& Fruit & Compute & ian & Fruit & on Class \\
& Time & r & Fruit & Time & Love the \\
& Math & Experime & Time & Manda & Nation \\
& Target & nt & Math & rin & Profil/Pa \\
& Time & Target & Target & Target & rents \\
& Evaluati & Time & Time & Time & Class \\
& on & Evaluatio & Evaluat & Evaluat & Target \\
& Lunch & n & ion & ion & Time \\
& & Lunch & Lunch & Lunch & $\begin{array}{l}\text { Evaluati } \\
\text { onLunch }\end{array}$ \\
\hline
\end{tabular}


TABLE II. LEARNING OUTCOMES INDICATORS

Table I, cont.

\begin{tabular}{|c|c|c|c|c|c|}
\hline \multirow{10}{*}{2} & Morning & English & Mornin & Mornin & Morning \\
\hline & $\begin{array}{l}\text { Dew } \\
\text { Social }\end{array}$ & $\begin{array}{l}\text { Fruit } \\
\text { Time }\end{array}$ & $\begin{array}{l}\text { g Dew } \\
\text { Indones }\end{array}$ & $\begin{array}{l}\text { g Dew } \\
\text { Math }\end{array}$ & $\begin{array}{l}\text { Dew } \\
\text { Motivati }\end{array}$ \\
\hline & Study & Compute & ian & Fruit & on Class \\
\hline & Fruit & $\mathrm{r}$ & Fruit & Time & Sport \\
\hline & Time & Science & Time & Manda & Entrepre \\
\hline & Math & Target & Math & rin & neurship \\
\hline & Target & Time & Target & Target & Planning \\
\hline & Time & Evaluatio & Time & Time & Target \\
\hline & $\begin{array}{l}\text { Evaluati } \\
\text { on }\end{array}$ & $\begin{array}{l}\mathrm{n} \\
\text { Lunch }\end{array}$ & $\begin{array}{l}\text { Evaluat } \\
\text { ion }\end{array}$ & $\begin{array}{l}\text { Evaluat } \\
\text { ion }\end{array}$ & $\begin{array}{l}\text { Time } \\
\text { Evaluati }\end{array}$ \\
\hline & Lunch & & Lunch & Lunch & $\begin{array}{l}\text { on } \\
\text { Lunch }\end{array}$ \\
\hline & Morning & English & Mornin & Mornin & Motivati \\
\hline \multirow[t]{12}{*}{3} & Dew & Fruit & g Dew & g Dew & on Class \\
\hline & Civic & Time & Present & Math & Entrepre \\
\hline & Fruit & Compute & ation & Fruit & neurship \\
\hline & Time & $\mathrm{r}$ & Fruit & Time & Target \\
\hline & Math & Science & Time & Manda & Time \\
\hline & Target & Target & Math & rin & Evaluati \\
\hline & Time & Time & Target & Target & \\
\hline & Evaluati & Evaluatio & Time & Time & Lunch \\
\hline & & & Evaluat & Evaluat & \\
\hline & Lunch & Lunch & ion & & \\
\hline & & & Lunch & Lunch & \\
\hline & Morning & English & Mornin & Mornin & Study \\
\hline \multirow[t]{11}{*}{4} & Dew & Fruit & g Dew & g Dew & Tour/Out \\
\hline & Social & Time & Indones & Math & ing \\
\hline & Fruit & Compute & ian & Fruit & \\
\hline & Time & $\mathrm{r}$ & Fruit & Time & \\
\hline & Math & Science & Time & Manda & \\
\hline & Target & Target & Math & rin & \\
\hline & Time & Time & Target & Target & \\
\hline & Evaluati & Evaluatio & Time & Time & \\
\hline & on & & Evaluat & Evaluat & \\
\hline & Lunch & Lunch & ion & ion & \\
\hline & & & Lunch & Lunch & \\
\hline
\end{tabular}

In the process of learning at Lentera Bangsa Community Homeschool, every student is given learning modules for mandatory subjects and the development of skills subjects that must be solved. Students are given the freedom to set targets for learning materials they need to accomplish each day with at least one worksheet per day for the subjects that are scheduled. Each student must complete the targets they set on that day, if they cannot solve these targets until the time limit then they have to add the class period until the target is reached. If the target is still not completed until the time that teachers think it is too long, they should bring the sheet work as a homework. If the students are able to complete the target well, then the students do not need to be given homework assignments unless it is on the demand of the students or if the teachers see that students need to be given additional tasks. By determining the learning targets independently by the students, they can measure, responsible and able to customize their learning speed.

The Learning Outcomes Assessment Indicators are defined as in Table 2.

\begin{tabular}{ll}
\hline $\begin{array}{l}\text { Learning } \\
\text { Outcomes } \\
\text { Indicators }\end{array}$ & Explaination \\
\hline Worksheet & $\begin{array}{l}\text { Assesment on all learning activities in the form of } \\
\text { worksheets, exercises, observation, social studies, } \\
\text { presentations, experiments/trials, task when outing } \\
\text { activities/excursions out is executed and discussion. }\end{array}$ \\
Pre Mid Exam & $\begin{array}{l}\text { Assessment on the result of work questions practice } \\
\text { which are made similar to the Middle Exam questions } \\
\text { with the aim to make the students more prepared in } \\
\text { understanding the Middle Exam's question form and } \\
\text { object. }\end{array}$
\end{tabular}

Mid Exam

Assessment on the result of work questions practice which are made based on topic and learning objectives through each subject in less than 3 months.

Pre Final Exam Assessment on the result of work questions practice which are made similar to Final Exam questions with the aim to make the students more prepared in terms of understanding the Final Exam's question form and object.

Final Exam

Assessment on the result of work questions practice which are made based on topic and learning objectives through each subject not more than 6 months.

Project Final Exam Assessment on the results of project work which are undertaken in the parents' assistance, which aims to hone creativity and a child's ability in understanding the learning object in less than 6 months.

Fun Evaluation

Assessment on the result of work questions practice which are made with the intention to set the children in a situation of formal examinations, but with the mild questions, creative and fun to work with.

With the concept of independent self-targeting by the students, it is found that any material processing rate of students will always be different from one another, so learning outcomes assessment indicators exercising time of each learner is also different. It was determined that each student can complete worksheets and implement Pre Middle Exam, Middle Exam, Pre Final Exam and Final Exams in accordance with their respective speed. However, for the implementation of the Final Exam Project and Fun Evaluation should be carried out at a predefined time and simultaneously.

Besides, each parent is required to accompany and provide facilities for the development of talent or potency of each student and must hold a good two-way communication with the school in order to monitor the students' talent development program. The school also requires each student to select at least one type of compulsory extracurricular provided by the school.

\section{B. Teachers, Students and Parents Feedback}

Referring to the observations and interviews with teachers, the implementation of the andragogical to pedagogical approach concept to the learning process illustrates that teachers are able to do a good management classroom. However, within a certain time it is found that teachers feel a little difficult with the difference in learning speed of each 
student when it comes to deliver some of the material which should be delivered in the classical style.

In this concept students feel more motivated to complete their targets quickly, because unconsciously they compete with each other. However, teachers should be able to be sensitive and to maintain control in the learning process so that students truly understand with the learning materials and not simply to chase speed.

In this case, the parents can be actively involved in the learning process of each children. For children who need special assistance in accomplishing their goals, their parents should be able to contribute directly in assisting their learning process at home.

\section{CONCLUSION, OBSTACLE, AND RECOMMENDATION}

Andragogical to pedagogical concept applied in the learning process of Lentera Bangsa Community Homeschool gives a positive impact on the completion of speed learning the differences and motivation of each student. So that each student is able to customize the learning targets with their own capabilities. This makes the students, parents and teachers are not depressed by the failure to achieve a learning target in some students at the same time, so that students, parents and teachers are able to focus more on providing learning programs that fit the needs of each learner and to the things that are able to develop the students' potencies.

The obstacles found in the implementation of the andragogical-pedagogical approach program in this learning process are:

1. Some students who do not really understand the learning materials, tend to compete to be the fastest.

2. For students who are academically capable but their orientation is not a goal oriented, tend to not finishing a lot of material in one lesson.

3. Difficulties which are experienced by educator when the teaching materials require the classical models explanation, caused by the different materials of each student which are according to their learning speed.

4. Parents, who want their children to be superior than their friends, tend to set targets in their children's learning process.

Based on the analysis and discussion of the findings of the study, the researcher gave several suggestions for further research as follows:

1. It is expected that research on learning model with andragogical to pedagogical approach can be developed by adding learning models which are creative and interactive in accordance with the needs in all aspects of the learning process.

2. Every educators should be able to master all the material and have the ability to design creative and interactive lesson plans so that they are competent in the implementation of the program.

3. Deep socialization to the parents related with the andragogical to pedagogical approach learning program is required so that all parents are able to understand the foundation of the running program.

\section{REFERENCES}

[1] Trifonas, Peter Pericles. Revolutionary pedagogies: cultural politics, instituting education, and the discourse of theor. London : Routledge. 2000.

[2] Beard, Colin (Colin M.). The experiential learning toolkit : blending practice with concepts. United States : Kogan Page Limited. 2010.

[3] Jarvis, Peter. Adult Education and Lifelong Learning 3rd Edition Teory and Practice. London : RoutledgeFalmer. 2004.

[4] Gibbons, Maurice. The Self-Directed Learning Handbook. San Fransisco : Jossey-Bas. 2002.

[5] Pritchard, Alan. Way of Learning : Learning Theories and Learning Styles in The Classroom. New York : Routledge. 2009.

[6] Pritchard, Alan and J. Woollard. Psychology For The Classroom : Constructivism and Social Learning. New York : Routledge. 2010.

[7] Maynard, Ashley E and Mary I. Martini. Learning in Cultural Context : Family, Peers and School. New York : Kluwer Academic/Plenum Publishers. 2005.

[8] Novic, Bernard, Jeffrey S. Kress and Maurice J. Elias. Building Learning Comunities With Character. USA : Association for Supervision and Curriculum Development (ASCD). 2002.

[9] Kumpulainen, Kristiina and David Wray. Classroom Interaction and Social Learning : From Theory to Practice. New York : RoutledgeFalmer. 2002.

[10] Gretler, Meric S and David A. Wolfe. Innovation and Social Learning. New York : Palgrave Macmillan. 2002.

[11] Reynolds, Michael and Russ Vince. Experiential Learning and Management Education. New York : Oxford University Press. 2007.

[12] Zajda, Joseph. Global Pedagogies : Schooling for The Future. New York : Springer Science+Business Media B.V. 2010.

[13] Kincheloe, Joe L. Knowledge and Critical Pedagogy. New York : Springer Science+Business Media B.V. 2008. 